\title{
Improvement of the efficiency of triple junction $n-i-p$ solar cells with hot-wire CVD proto- and microcrystalline silicon absorber layers
}

\author{
R.L. Stolk *, H. Li, R.H. Franken, J.W.A. Schüttauf, C.H.M. van der Werf, J.K. Rath, R.E.I. Schropp \\ Utrecht University, Faculty of Science, SID-Physics of Devices, P.O. Box 80.000, 3508 TA Utrecht, The Netherlands
}

Available online 18 June 2007

\begin{abstract}
Hot-wire chemical vapour deposition (HWCVD) was applied for the deposition of intrinsic protocrystalline (proto-Si:H) and microcrystalline silicon ( $\mu \mathrm{c}-\mathrm{Si}: \mathrm{H})$ absorber layers in thin film solar cells. For a single junction $\mu \mathrm{c}-\mathrm{Si}: \mathrm{H} \mathrm{n}-\mathrm{i}-\mathrm{p}$ cell on a Ag/ZnO textured back reflector (TBR) with a $2.0 \mu \mathrm{m}$ i-layer, an $8.5 \%$ efficiency was obtained, which showed to be stable after $750 \mathrm{~h}$ of light-soaking. The short-circuit current density $\left(J_{\text {sc }}\right)$ of this cell was $23.4 \mathrm{~mA} / \mathrm{cm}^{2}$, with a high open-circuit voltage $\left(V_{\mathrm{oc}}\right)$ and fill factor $(\mathrm{FF})$ of $0.545 \mathrm{~V}$ and 0.67.

Triple junction $\mathrm{n}-\mathrm{i}-\mathrm{p}$ cells were deposited using proto-Si:H, plasma-deposited proto-SiGe:H and $\mu \mathrm{c}-\mathrm{Si}: \mathrm{H}$ as top, middle and bottom cell absorber layers. With Ag/ZnO TBR's from our lab and United Solar Ovonic LLC, respective initial efficiencies of $10.45 \%\left(2.030 \mathrm{~V}, 7.8 \mathrm{~mA} / \mathrm{cm}^{2}\right.$, $0.66)$ and $10.50 \%\left(2.113 \mathrm{~V}, 7.4 \mathrm{~mA} / \mathrm{cm}^{2}, 0.67\right)$ were achieved.
\end{abstract}

(C) 2007 Elsevier B.V. All rights reserved.

Keywords: Hot-wire; CVD; Microcrystalline silicon; Multijunction; Textured back reflector; Profiling

\section{Introduction}

In the past decade, hot-wire chemical vapour deposition (HWCVD) has become a mature method for the preparation of high quality silicon materials for application in thin film transistors and solar cells. In our group, we have developed HWCVD intrinsic protocrystalline silicon (proto-Si:H), which, compared to amorphous silicon, is characterized by an enhanced medium range structural order and a higher stability against light-soaking [1], and microcrystalline silicon ( $\mu \mathrm{c}-\mathrm{Si}: \mathrm{H})$. Both materials were successfully applied in thin film solar cells on plain stainless steel $[2,3]$. In order to make a better use of the energy present in the solar spectrum, multijunction, multi band gap structures are required. Previously, we reported a 5.3\% efficiency for a proto-Si $/ \mu \mathrm{c}-\mathrm{Si} / \mu \mathrm{c}-\mathrm{Si}$ triple junction cell on plain stainless steel [4]. To enhance this efficiency, we made two major and necessary changes to our cell design. First, the $\mu \mathrm{c}-\mathrm{Si}: \mathrm{H}$ absorber layer of the middle cell was replaced by plasma-enhanced chemical vapour-deposited (PECVD) protocrystalline silicon-germanium (proto-SiGe:H), which is highly stable against light-soaking [5]. This allows for a more efficient

\footnotetext{
* Corresponding author.

E-mail address: r.1.stolk@phys.uu.nl (R.L. Stolk).
}

spectral splitting and, therefore, in principle, a higher solar cell efficiency. The wider band gap will increase the open-circuit voltage $\left(V_{\mathrm{oc}}\right)$. Second, a textured back reflector $(\mathrm{TBR})$ was incorporated in the cell to boost the short-circuit current density $\left(J_{\mathrm{sc}}\right)$. Additionally, the n-layer deposition of the $\mu \mathrm{c}-\mathrm{Si}: \mathrm{H}$ bottom cell was optimized and the $n /$ i-interface and i-layer of this cell were profiled to improve its performance [6]. A schematic picture of the triple junction cell structure can be found in Fig. 1. In this paper, we report recent results for the improved single junction $\mu \mathrm{c}-\mathrm{Si}: \mathrm{H}$ bottom cell and the triple junction cell.

\section{Experimental details}

The silicon layers of the $\mathrm{n}-\mathrm{i}-\mathrm{p}$ structured solar cells were deposited in the PASTA multi-chamber ultra-high vacuum system. Details of the cell structures can be found in $[3,7,8]$. Doped layers and intrinsic proto-SiGe:H [8] were prepared using 13.56 MHz PECVD, whereas HWCVD was applied to fabricate intrinsic proto-Si:H [2] and $\mu \mathrm{c}-\mathrm{Si}: \mathrm{H}[4,9]$. For the hotwire deposition, two straight Ta filaments with a diameter of $0.5 \mathrm{~mm}$ were used, through which a current of $10.5 \mathrm{~A}$ was passed, yielding a wire temperature of $1850{ }^{\circ} \mathrm{C}$ (vacuum calibration). The calibrated substrate temperature was $250{ }^{\circ} \mathrm{C}$. Proto-Si:H was deposited from undiluted $\mathrm{SiH}_{4}$, whereas $\mathrm{H}_{2}$ - 


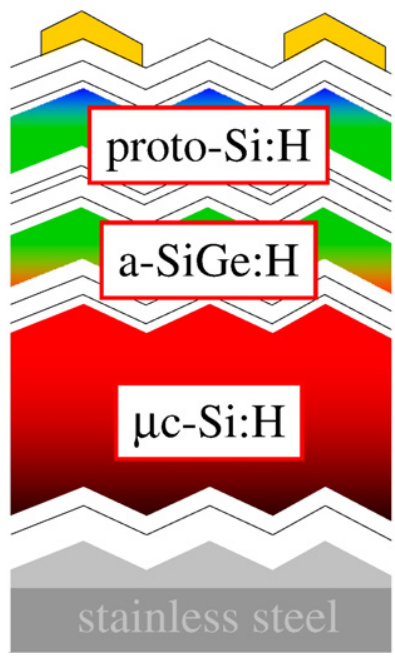

Fig. 1. Schematic picture of a triple junction thin film solar cell deposited onto a stainless steel substrate with a textured back reflector. The different subcell absorber materials are indicated; on top of the silicon layers is an indium-tinoxide/gold contact.

diluted $\mathrm{SiH}_{4}$ with a $\mathrm{H}_{2}$ dilution $\left(\mathrm{H}_{2}\right.$-flow/total gas flow) of around 0.95 was used for the $\mu \mathrm{c}-\mathrm{Si}: \mathrm{H}$ deposition. The respective deposition rates were 10 and $2.1 \AA / \mathrm{s}$. The $\mu \mathrm{c}-\mathrm{Si}: \mathrm{H}$ is so-called mixed phase or transition material, consisting of nanocrystallites in an a-Si:H matrix $[3,9]$.

Two types of substrates were used: a $\mathrm{Ag} / \mathrm{ZnO}$ TBR made on stainless steel (SS) foil in our laboratory $[10,11]$ and a SS/Ag/ $\mathrm{ZnO}$ substrate provided to us by United Solar Ovonic LLC Corporation. Indium-tin-oxide served as an anti-reflecting TCO top window; an evaporated gold grid on top facilitated a proper charge carrier collection. Both the metal oxide layers and the textured $\mathrm{Ag}$ of the TBR were deposited by magnetron sputtering in our SALSA system $[10,11]$. The active area of the solar cells was $0.13 \mathrm{~cm}^{2}$. Light $J-V$ measurements were conducted with the use of a mask to prevent current collection from outside the cell area.

\section{Results and discussion}

Fig. 2 shows the spectral response (SR) curves of two single junction $\mu \mathrm{c}-\mathrm{Si}: \mathrm{H}$ cells, both with $2.0 \mu \mathrm{m}$ thick HWCVD absorber layers. The dashed curve was obtained for a cell on plain SS, with an i-layer grown with a constant hydrogen dilution of 0.952; the solid curve represents an optimized cell on a TBR deposited in our lab $[10,11]$. For this cell, the n-layer was optimized, the i-layer deposition was started somewhat below the equilibrium substrate temperature of $250{ }^{\circ} \mathrm{C}$ ('dynamic start') and the hydrogen dilution was 'reversely' profiled by changing the silane flow by $10 \%$ halfway the i-layer deposition: the bottom half was grown at a hydrogen dilution of 0.948 , the upper half at a higher dilution of 0.952 . For plasma-deposited i-layers, the hydrogen dilution is usually decreased during growth instead of increased. In this way, a too high crystallinity of the layer, which adversely affects the quality of the i-layer and the $\mathrm{p} / \mathrm{i}-(\mathrm{n}-\mathrm{i}-\mathrm{p}$ cells $)$ or $\mathrm{i} / \mathrm{n}$-interface $(\mathrm{p}-\mathrm{i}-\mathrm{n}$ cells $)$, is prevented. In the case of the hot-wire deposition of $\mu \mathrm{c}-\mathrm{Si}: \mathrm{H}$

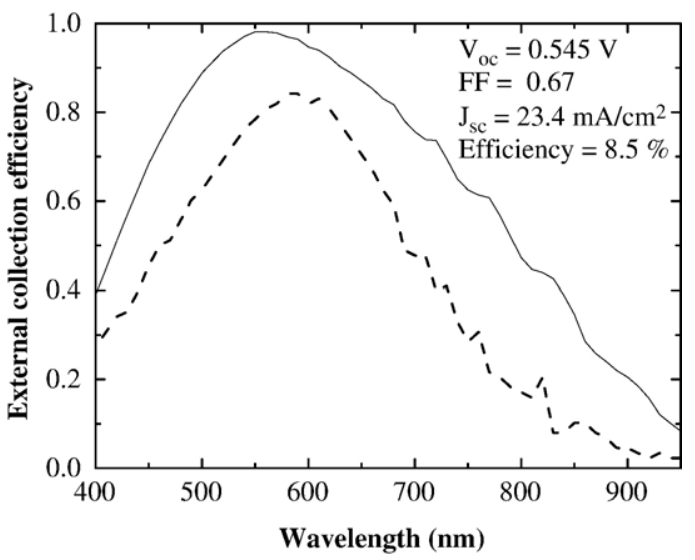

Fig. 2. Improvement of the SR of a $2.0 \mu \mathrm{m} \mu \mathrm{c}-\mathrm{Si}: H$ solar cell on a TBR (solid line) with respect to that of a $2.0 \mu \mathrm{m}$ cell on plain stainless steel (dashed line). The AM1.5 light $J-V$ parameters of the cell on the TBR are shown.

transition material, the crystallinity tends to decrease with an increasing layer thickness, which, after a certain thickness, results in an amorphous upper part of the layer [9]. This is in contrast with what is generally observed for plasma-enhanced CVD [12-15]. To stay on the microcrystalline side of the amorphous-to-microcrystalline phase transition, the hydrogen dilution is, as indicated above, increased after half of the layer
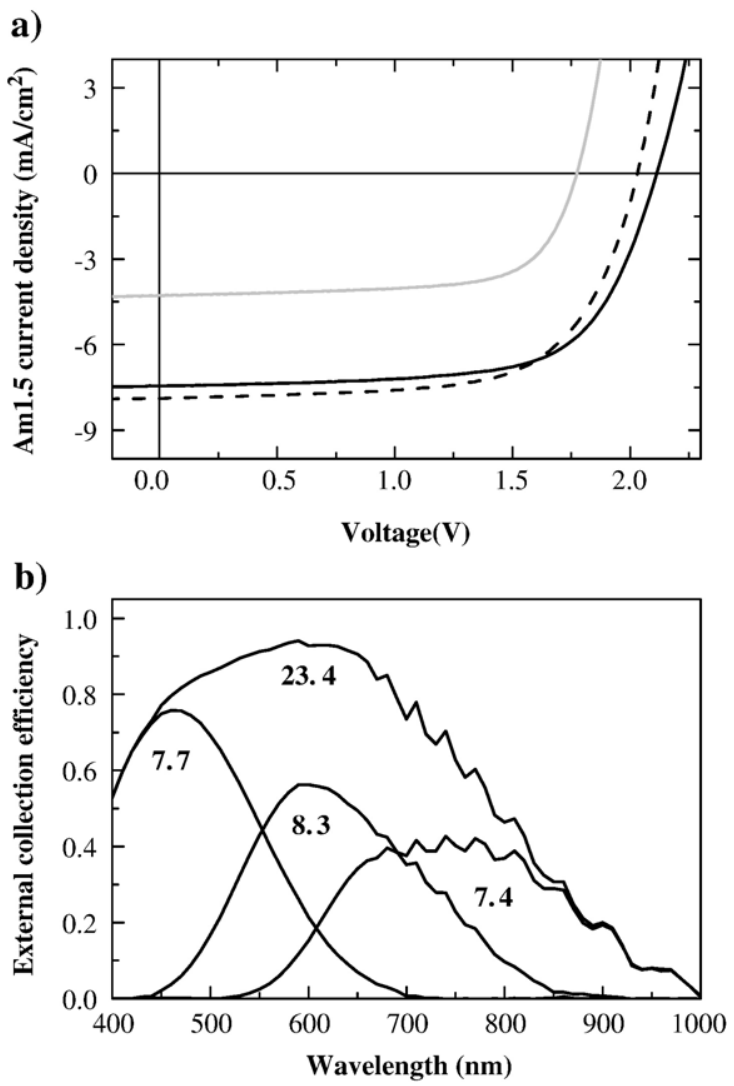

Fig. 3. a) AM1.5 light $J-V$ curves of a proto-Si:H/ $\mu c-S i: H / \mu c-S i: H$ triple junction $\mathrm{n}-\mathrm{i}-\mathrm{p}$ cell on plain stainless steel (grey line) and proto-Si:H/protoSiGe:H/ $/$ c-Si:H cells on SS/Ag/ZnO TBRs deposited at our lab (dashed line) and provided by United Solar (black line) b) Subcell and added SR of the latter. 
Table 1

AM1.5 light $J-V$ parameters of the three triple junction solar cells shown in Fig. $3 \mathrm{a}$

\begin{tabular}{|c|c|c|c|c|}
\hline Cell & $\begin{array}{l}V_{\mathrm{oc}} \\
(\mathrm{V})\end{array}$ & $\begin{array}{l}J_{\mathrm{sc}} \\
\left(\mathrm{mA} / \mathrm{cm}^{2}\right)\end{array}$ & $\mathrm{FF}$ & $\begin{array}{l}\text { Efficiency } \\
(\%)\end{array}$ \\
\hline Proto-Si/ $\mu \mathrm{c}-\mathrm{Si} / \mu \mathrm{c}-\mathrm{Si}$ on $\mathrm{SS}$ & 1.772 & 4.4 & 0.69 & 5.3 \\
\hline $\begin{array}{l}\text { Proto-Si/proto-SiGe/ } \mu \mathrm{c}-\mathrm{Si} \text { on } \\
\mathrm{SS} / \mathrm{Ag} / \mathrm{ZnO} \mathrm{TBR} \text { (Utrecht University) }\end{array}$ & 2.030 & 7.8 & 0.66 & 10.45 \\
\hline $\begin{array}{l}\text { Proto-Si/proto-SiGe/ } \mu \text { c-Si on } \\
\text { SS/Ag/ZnO TBR (Unisolar) }\end{array}$ & 2.113 & 7.4 & 0.67 & 10.50 \\
\hline
\end{tabular}

has been deposited. More details on the optimization of the $\mu \mathrm{c}-\mathrm{Si}: \mathrm{H}$ cell can be found in a separate paper at this conference [6].

It can be seen that the SR of the cell on the TBR has increased throughout the measured wavelength range [3], which is very likely due to a combination of enhanced light-trapping and a reduced reflection at the rougher front interface [16] of the cell. TEM images of single junction $\mu \mathrm{c}-\mathrm{Si}: \mathrm{H}$ solar cells confirm that the $\mu \mathrm{c}-\mathrm{Si}: \mathrm{H}$ solar cell stack conformably follows the roughness of a $\mathrm{Ag} / \mathrm{ZnO} \mathrm{BR}$. As a result, the front interface of a cell with a flat $\mathrm{Ag} / \mathrm{ZnO} \mathrm{BR}$ is flat, whereas a cell on a TBR has a front interface roughness similar to that of the back contact.

The cell's $J_{\text {sc }}$ of $23.4 \mathrm{~mA} / \mathrm{cm}^{2}$ is a good value for an i-layer of only $2.0 \mu \mathrm{m}$ thick, and the $V_{\text {oc }}$ of $0.545 \mathrm{~V}$ and FF of 0.67 are amongst the better values found for this type of cells $[17,18]$. The cell efficiency of $8.5 \%$ is a record value for a single junction $\mu \mathrm{c}-\mathrm{Si}: \mathrm{H} \mathrm{n}-\mathrm{i}-\mathrm{p}$ cell with a hot-wire absorber layer. It is in line with state-of-the-art results for similar cells with VHF plasmaenhanced CVD i-layers (8.99\%) [17]. After $750 \mathrm{~h}$ of lightsoaking at $50{ }^{\circ} \mathrm{C}$ and near AM1.5 illumination intensity, the $V_{\text {oc }}$ and $\mathrm{FF}$ of the cell were unchanged, showing that the cell is stable against light-soaking. The $J_{\mathrm{sc}}$ was $2.6 \%$ (relative) lower than the initial $J_{\mathrm{sc}}$, which lies within the accuracy that can be achieved with our solar simulator set-up.

Fig. 3a shows the results of light $J-V$ measurements of three triple junction solar cells. It compares our previously presented results for a proto-Si:H/ $\mu \mathrm{c}-\mathrm{Si}: \mathrm{H} / \mu \mathrm{c}-\mathrm{Si}: \mathrm{H}$ cell on plain stainless steel to our up-to-date achievements for proto-Si:H/proto-SiGe: $\mathrm{H} / \mu \mathrm{c}-\mathrm{Si}: \mathrm{H}$ triples on SS/TBR substrates. The best cells on both our in-house developed TBR and on a Unisolar substrate are displayed. Table 1 lists the AM1.5 light $J-V$ parameters of the three cells.

It can be seen that the changes to our cell design have greatly increased the $V_{\mathrm{oc}}$ and $J_{\mathrm{sc}}$ of the triple junction cells. The former can be attributed to the improvement of the bottom cell and to the improved spectral splitting due to the proto-SiGe:H middle cell absorber layer, the latter to the use of a TBR. Compared to the old triple junction cell stack, the efficiency, which is now $10.50 \%$ for the cell on the Unisolar substrate, has nearly doubled. Meanwhile, the use of the strongly absorbing proto$\mathrm{SiGe}: \mathrm{H}$ in the middle cell decreased the total active layer thickness from over $3.0 \mu \mathrm{m}$ to just above $2.5 \mu \mathrm{m}$. From the SR of the cell on the Unisolar TBR (Fig. 3b) it follows that the bottom cell is limiting the output current and that the subcell currents are matched quite well. The improvement of the subcell current matching with respect to that of the triple cell on plain stainless steel may be the cause for the slightly lower FF of the present triple cell [19]. An equal distribution of the total current of $23.4 \mathrm{~mA} / \mathrm{cm}^{2}$ over the three subcells in the triple cell stack would increase $J_{\text {sc }}$ by about $5 \%$ and could also enhance $V_{\text {oc }}$. Apart from a better matching of the subcell currents, further room for improvement lies in an optimization of the subcell properties and a more efficient light-trapping.

\section{Summary and conclusions}

Solar cell characteristics and spectral responses were presented of thin film silicon $n-i-p$ solar cells with hot-wire chemical vapour-deposited absorber layers. For a single junction cell with a $2.0 \mu \mathrm{m} \mu \mathrm{c}-\mathrm{Si}: \mathrm{H}$ intrinsic layer on a $\mathrm{ZnO} /$ $\mathrm{Ag}$ TBR, sputtered onto SS, an efficiency of $8.5 \%$ was obtained, with a $V_{\mathrm{oc}}, J_{\mathrm{sc}}$ and fill factor (FF) of $0.545 \mathrm{~V}, 23.4 \mathrm{~mA} / \mathrm{cm}^{2}$ and 0.67 . This efficiency, which proved to be stable after $750 \mathrm{~h}$ of light-soaking at $50{ }^{\circ} \mathrm{C}$, is a record value for this type of cells with a hot-wire $\mu \mathrm{c}-\mathrm{Si}: \mathrm{H}$ absorber layer. Proto-Si:H/proto-SiGe: $\mathrm{H} / \mu \mathrm{c}-\mathrm{Si}: H$ triple junction cells with hot-wire top and bottom cell absorber layers, deposited onto TBRs prepared at our lab and provided by United Solar, showed greatly improved cell efficiencies with respect to earlier results for cells on plain stainless steel. The highest efficiency, obtained on a Unisolar TBR, was $10.50 \%$, with a $V_{\text {oc }}$ of $2.113 \mathrm{~V}$, a $J_{\text {sc }}$ of $7.4 \mathrm{~mA} / \mathrm{cm}^{2}$ and a FF of 0.67 .

\section{Acknowledgements}

We thank United Solar Ovonic LLC for providing stainless steel substrates with textured $\mathrm{Ag} / \mathrm{ZnO}$ coatings. The research was financially supported by SenterNovem.

\section{References}

[1] R.E.I. Schropp, M.K. van Veen, C.H.M. van der Werf, D.L. Williamson, A.H. Mahan, Proceedings of the 19th European Photovoltaic Solar Energy Conference, Paris (France), June 2004, p. 1526.

[2] M.K. van Veen, R.E.I. Schropp, Appl. Phys. Lett. 82 (2003) 287

[3] R.L. Stolk, H. Li, R.H. Franken, J.J.H. Strengers, C.H.M. van der Werf, J.K. Rath, R.E.I. Schropp, J. Non-Cryst. Solids 352 (2006) 1933.

[4] R.L. Stolk, H. Li, C.H.M. van der Werf, R.E.I. Schropp, Thin Solid Films 501 (2006) 256.

[5] A. Gordijn, R. Jimenez Zambrano, J.K. Rath, R.E.I. Schropp, IEEE Trans. Electron Devices 49 (2002) 949.

[6] H. Li, R.H. Franken, R.L. Stolk, C.H.M. van der Werf, J.K. Rath, R.E.I. Schropp, Thin Solid Films (in press).

[7] R.L. Stolk, J.J.H. Strengers, H. Li, R.H. Franken, C.H.M. van der Werf, J.K. Rath, R.E.I. Schropp, Proc. 20th PVSEC, 6-10 June 2005, Barcelona, 2005, p. 1655, Spain.

[8] H. Li, R.L. Stolk, C.H.M. van der Werf, R.H. Franken, J.K. Rath, R.E.I Schropp, J. Non-Cryst. Solids 352 (2006) 1941.

[9] M.K. van Veen, Ph.D. thesis, Utrecht University, the Netherlands, 2003.

[10] R.H. Franken, R.L. Stolk, H. Li, C.H.M. van der Werf, J.K. Rath, R.E.I. Schropp, J. Appl. Phys. 102 (2007) 014503.

[11] R.H. Franken, R.L. Stolk, H. Li, C.H.M. van der Werf, J.K. Rath, R.E.I. Schropp, Proceedings of the 21st European Photovoltaic Solar Energy Conference, Dresden (Germany), September 2006, pp. 1565, 1744.

[12] G.M. Ferreira, A.S. Ferlauto, Chi Chen, R.J. Koval, J.M. Pearce, C. Ross, C.R. Wronski, R.W. Collins, J. Non-Cryst. Solids 338-340 (2004) 13

[13] B. Yan, G. Yue, J. Yang, S. Guha, D.L. Williamson, D. Han, Chun-Seng Jiang, Appl. Phys. Lett. 85 (2004) 1955. 
[14] A.V. Shah, J. Meier, E. Vallat-Sauvain, N. Wyrsch, U. Kroll, C. Droz, U. Graf, Sol. Energy Mater. Sol. Cells 78 (2003) 469.

[15] O. Vetterl, F. Finger, R. Carius, P. Hapke, L. Houben, O. Kluth, A. Lambertz, A. Mück, B. Rech, H. Wagner, Sol. Energy Mater. Sol. Cells $62(2000) 97$.

[16] S. Koynov, M.S. Brandt, M. Stutzmann, Appl. Phys. Lett. 88 (2006) 203107.
[17] B. Yan, G. Yue, J.M. Owens, J. Yang, S. Guha, Presented at the 4th WCPEC, 7-12 May 2006, Waikoloa Village, Hawaii (USA), 2006.

[18] O. Vetterl, A. Lambertz, A. Dasgupta, F. Finger, B. Rech, O. Kluth, H. Wagner, Sol. Energy Mater. Sol. Cells 66 (2001) 345.

[19] R.L. Stolk, H. Li, R.H. Franken, C.H.M. van der Werf, J.K. Rath, R.E.I. Schropp, Mater. Res. Soc. Symp. Proc. 910 (2006) A26.03. 